UDC 336.26

DOI: https://doi.org/10.32782/easterneurope.28-12

\title{
FISCAL DECENTRALIZATION IN UKRAINE: THEORETICAL AND APPLIED PROBLEMS OF DEVELOPMENT
}

\author{
ФІСКАЛЬНА ДЕЦЕНТРАЛІЗАЦІЯ В УКРАЇНІ: \\ ТЕОРЕТИЧНІ ТА ПРИКЛАДНІ ПРОБЛЕМИ РОЗВИТКУ
}

\author{
Kriuchkova Nataliia \\ $\mathrm{PhD}$ in Economics, Associate Professor, \\ Senior Lecturer at Department of Economics and Business, \\ Odessa I.I. Mechnikov National University \\ ORCID: https://orcid.org/0000-0003-3790-4399
}

Крючкова Н.М. кандидат економічних наук, доцент, доцент кафредри економіки та підприємництва, Одеський національний університет імені І.І. Мечникова

Advantages of decentralization processes and their implementation in modern transformational conditions of development are justified. It is proposed to systematize the effects of fiscal decentralization, in particular the direct and indirect effects and relevant socio-economic factors that influence the effectiveness of the implementation of fiscal decentralization. Based on generalized methodological approaches to the assessment of fiscal decentralization, the dynamics of fiscal decentralization parameters in Ukraine is analyzed, in particular: dynamics of the share of local budget revenues in Ukraine, which tends to increase the share of transfers and, accordingly, the share of own revenues; the share of local budget revenues in the structure of revenues and expenditures of the consolidated budget of Ukraine (the coefficient of decentralization by revenues and expenditures) - marked different dynamics for the analyzed period of time. As part of the study of prospects for fiscal decentralization as a factor in the development of regions of Ukraine, modeling of indicative parameters of fiscal decentralization based on the construction of a regression model in terms of 4 explanatory variables: own revenues per capita, distance from the regional center, the level of subsidies maintenance of the management staff in the financial resources.

Key words: fiscal decentralization, effects of fiscal decentralization, local budgets, coefficients of decentralization, own incomes, level of budget subsidization, indicative parameters of fiscal decentralization.

В статье обоснованы преимущества децентрализации и ее имплементации в современных трансрормационных условиях развития. Предложено систематизацию эффректов фииккальной децентрализации, в частности выделены прямые и косвенные эфрфекты и соответствующие социально-экономические фракторы, которые оказывают влияние на результативность внедрения фрискальной децентрализации. На основании обобщенных методических подходов к оценке фрискальной децентрализации проанализирована динамика параметров фрискальной децентрализации в Украине, в частности: динамики удельного веса доходов местных бюджетов в Украине, который имел тенденцию к росту доли трансфертов и, соответственно, тенденцию к снижению удельного веса собственных доходов; доли доходов местных бюджетов в структуре доходов и расходов сводного бюджета Украины (коэфффициент децентрализации по доходам и по расходам) - отмечено разнонаправленную динамику за рассматриваемый период времени. В рамках исследования перспектив развития фрискальной децентрализации как фрактора развития регионов Украины осуществлено моделирование индикативных параметров фискальной децентрализации на основе построения регрессионной модели в разрезе 4 объясняющих переменных: собственных доходов на одного жителя, удаленности от областного центра региона, уровень дотационности бюджетов, удельного веса расходов на содержание аппарата управления.

Ключевые слова: фискальная децентрализация, эфрфекты фрискальной децентрализации, местные бюджеты, коэффрициенты децентрализации, собственные доходы, уровень дотационности бюджетов, индикативные параметры фрискальной децентрализации.

Обірунтовано сутність фріскальної децентралізації в сучасній теорії та практиці як процес передачі видаткових повноважень і джерел їх фрінансування на нижчі рівні державного управління, що забезпечує фріскальну автономію регіональної та місцевої влади, а також підвищення транспарентності і підзвітності 
процесу надання суспільних благ. В ході і аналізу ефектів фріскальної децентралізації виокремлено прямі ефректи - економічне зростання та цінова стабільність; регіональна економічна конвергенція; інституційний розвиток; та непрямі ефекти - мобільність населення; структура видатків; податкові витрати; працевлаштування. На підставі узагальнених методичних підходів до оцінки фріскальної децентралізації проаналізовано динаміку параметрів фріскальної децентралізації в Україні, зокрема: динаміки питомої ваги доходів місцевих бюджетів в Україні, що мав тенденцію до зростання частки трансфертів, та, відповідно, тенденцію до зниження питомої ваги власних доходів; частки доходів місцевих бюджетів у структурі доходів і видатків зведеного бюджету України (коефріцієнт децентралізації за доходами та за видатками) відзначено різноспрямовану динаміку за аналізований період часу. В рамках дослідження перспектив розвитку фріскальної децентралізації як чинника розвитку регіонів України здійснено моделювання індикативних параметрів фріскальної децентралізації на основі побудови регресійної моделі у розрізі 4 пояснюючих змінних: власних доходів на одного мешканця, віддаленості від обласного центру регіону, рівень дотаційності бюджетів ОТГ, питомої ваги видатків на утримання апарату управління у фрінансових ресурсах ОТГ. За результатами дослідження встановлено пряму залежність між обсягами капітальних видатків та обсягами власних доходів об'єднаних територіальних громад, та зворотну залежність між чисельністю населення та віддаленістю від обласного центра регіону. Надано відповідні пропозиції щодо вирішення виявлених під час дослідження проблем фріскальної децентралізації в Україні, зокрема: необхідність фрормування місцевих бюджетів за рахунок власних джерел надходжень, підвищення рівня їх самостійності та бездотаційності, оптимізація механізму державної підтримки регіонів, стимулювання територій з метою динамічного економічного розвитку.

Ключові слова: фріскальна децентралізація, ефекти фріскальної децентралізації, місцеві бюджети, коефіцієнти децентралізації, власні доходи, рівень дотаційності бюджетів, індикативні параметри фріскальної децентралізації.

Introduction. In the process of active implementation of the decentralization reform in Ukraine, the overall level of responsibility of Ukrainian society is increasing, which actively creates financially viable amalgamated territorial communities, capable of solving accumulated systemic socio-economic problems, and directly participates in the processes of territorial governance. Decentralization today is an opportunity for communities to have the authority and resources to meet the current needs of the region. The updated system of financial support of local budgets contributes to the growth of motivation to increase their income part, however, the current results of fiscal decentralization testify to the insufficiency of formed additional resources of local self-government bodies to finance selfgoverning powers and powers delegated by the state, as well as to increase regional efficiency.

Analysis of recent research and publications. Among foreign scholars who have been studying the issues of fiscal decentralization, it is worth noting the works by R. Barro, R. Boadway, G. Brennan, J. Buchanan, R. Masgrave, V. Oates, C. Tibu and others. An important contribution to the formation of the scientific paradigm of fiscal decentralization in the context of the transformation of the entire tax system and the problem of regional financial efficiency has been made by such scientists as V. Andrushchenko [1], T. Bogolib [2], Y. Ivanov [3], A. Krysovatyi [4], I. Lukianenko [5], I. Lunina [6], A. Mazaraki [7], V. Sidenko [8], V. Fedosov [9], S. Yurii [10] and others. Taking into consideration the basic research of scientists, it should be noted that these problems have not been studied yet, which, in turn, requires further research in this field. The development of democracy and the decentralization of the public sector are increasing the importance of these issues in the world. Since 1980, many countries have chosen decentralization as a path of development. Today, there is no standard model because the processes and procedures in each country differ, and also depend on the goals, objectives and organizational structure and mechanisms for their implementation.

The purpose of our research is to identify the theoretical and applied problems of fiscal decentralization development in Ukraine under the modern transformational conditions. To achieve this goal, the following tasks are set: to reveal the essence of fiscal decentralization in modern financial science and practice; to propose a systematization of the effects of fiscal decentralization; to present an assessment of fiscal decentralization and analyze the dynamics of its parameters; to substantiate directions of development of fiscal decentralization on the basis of modeling of indicative parameters.

The research will use the following methods: methods of analysis, synthesis, dialectical, systemic and structural methods; comparative, factor methods, methods of statistical analysis; methods of scientific abstraction, economic and mathematical modeling; abstract-logical method.

Results. The system of argumentation for fiscal decentralization implementation emerged at the beginning of the 20th century, and in general, comes out of economic theory and includes four main points.

Decentralization provides for a more efficient allocation and distribution of resources in the public sector. Decentralization contributes to increasing accountability of public authorities regarding the use of state budget resources. The essence of this argument is that with decentralization, the link 
between taxes levied and public goods provided becomes more transparent. The availability of the own tax base obliges regional and local authorities to take steps to expand it, that is, to encourage the development of local and regional economies. It promotes better management of local and regional taxes. Granting regional and local authorities the right to self-administer budgetary resources drives them to reduce the amount of inefficient spending in the real economy of the regions [11]. The principles of fiscal federalism continue to serve as a basis for evaluating local funding systems.

The current stage of decentralization in Ukraine started in 2015, which was reflected in the amendments to the Budget and Tax Codes of Ukraine. Local authorities have the right to formulate local budgets independently (regardless of the timing of the adoption of the state budget). The list of taxes forming the income part of local budgets has been expanded at the expense of $100 \%$ payment for administrative services, $100 \%$ state duty, 10\% income tax of 212 enterprises, retail sales of excisable goods, real estate tax, car tax on high engine volume, $80 \%$ environmental tax (instead of 35\%) and 25\% subsoil charges [12].

At the same time, local budgets lost part of their income from personal income tax - to the regional budgets comes $15 \%$, to the budgets of cities of regional importance $-60 \%$, to the state budget $-25 \%$, as a result, incomes to the state budget from PIT increased in 4.5 times, and local budget incomes decreased from 46 billion UAH to 38 billion $\mathrm{UAH}$, from $61.5 \%$ to $44.5 \%$ in the structure of local budget incomes [12].

According to the current stage of decentralization, the first step was the formation of capable territorial communities by identifying potential administrative centers of such communities.

In the context of increased geopolitical tensions and slowdown of economic dynamics, the number of regions whose budgets have been approved with deficits continues to grow in Ukraine, and the debt burden on local budgets of regions is increasing, which contributes to the aggravation of current and prospective problems of social and economic development [13].

The fiscal decentralization strategy in Ukraine should be based on an assessment of existing models of the country's tax and budget systems; the rights and responsibilities entrusted to local authorities in managing the country's financial resources; citizens' readiness for new powers of local authorities; increasing responsibility in the area of formation, distribution and use of financial resources by region; efficiency of selection of qualified personnel in the field of local self-government; the level of competence of local authorities, which are obliged to be able to ensure an efficient process of formation, distribution and use of financial resources of the regions of the country; the level of motivation of regional authorities and local selfgovernment to increase the efficiency of utilization of the economic, tax and budgetary potential of the region in order to ensure the integrity and comprehensive development of the state, as well as the financial autonomy of the regions [14].

In the study of the indirect consequences of fiscal decentralization, we focus on certain macroeconomic outcomes that may be affected by fiscal decentralization, which have been identified as potential determinants of poverty and income distribution. Some examples are economic growth, macroeconomic stability, regional convergence, the size of the public sector, and the degree of institutional development. To the extent that fiscal decentralization has a measurable impact on these outcomes, it is indirectly expected that it will also have a measurable impact on poverty and income distribution.

On the income side, fiscal decentralization can also affect the progressiveness of the tax system and, therefore, alter the distribution of disposable income. For example, local governments may be financed through user fees and indirect taxation, which are typically more regressive, or real estate taxes, which are generally less progressive than the tax system used by central governments.

In this context, high dependency on local tax collection can reduce the overall progressiveness of the tax system at the national level and thus affect the poverty level and income distribution (Figure 1).

In 2014-2015, a large number of regulatory documents regarding fiscal decentralization were adopted. The reform of intergovernmental budget relations, adopted in 2015 in Ukraine, is a crucial step in the budgetary and financial independence of local budgets:

- independent formation of local budgets (Article 75 of the Budget Code of Ukraine);

- adoption of the state budget, approval on the sites regardless of the deadline, but before December 25, the year preceding the planned one (according to Article 77 of the Budget Code of Ukraine);

- the process of providing local guarantees and making local borrowings from international financial institutions is simplified;

- granting the right to make local external loans to all cities of regional significance (Article 16 of the Budget Code of Ukraine);

- establishment of uniform rates of deductions of national-wide taxes (income tax for individuals and corporate income tax) for each budget link (Articles 64, 66, 69, 691 of the Budget Code of Ukraine);

- cancellation of indicative planning of local budget indicators by the Ministry of Finance of Ukraine and bringing them to local budgets;

- formation of a single basket of general fund incomes;

- expanding the list of sources of income of the general fund [15].

Since 2015, there have been changes in the structure of local taxes and fees and in local budget incomes. The most important innovation is the introduction of excise tax on sales of excisable goods by retailers in the amount of $5 \%$. 


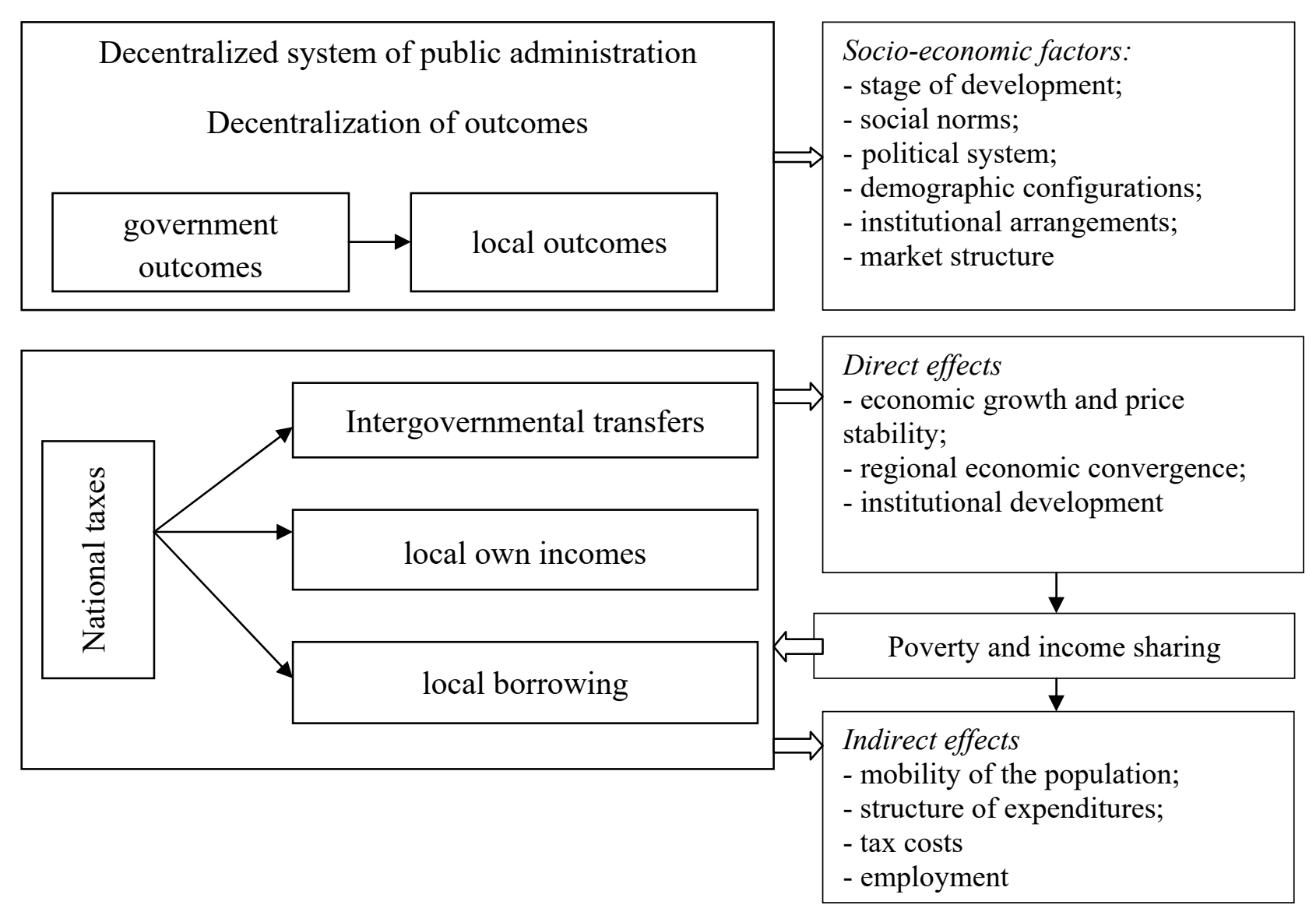

Figure 1. Effects of fiscal decentralization

Developed by the author

Also in 2015, the property tax was reformed by including in it a property tax other than land, transportation tax and land payments.

The simplified system of taxation of accounting and reporting has also been changed in the part of allocation in a separate fourth group of single tax of former payers of the fixed agricultural tax with corresponding preservation of crediting of this payment to local budgets.

The next step was the adoption of changes in 2016 concerning the strengthening of the income part of local budgets. In particular, a single rate of $18 \%$ for wage income has been introduced in the area of taxation on personal income tax.

A dynamics analysis of the share of local budget incomes in Ukraine showed a trend towards an increase in the share of transfers, starting from 2010 from 53\% in 2010 to 59\% in 2015 and, accordingly, a trend towards a decrease in the share of own incomes.

Thus, despite the increase in local budget incomes in 2015, the share of transfers in local budget incomes has also increased.

Another important indicator is the share of local budget incomes in the structure of consolidated budget incomes of Ukraine (coefficient of decentralization by income) (Figure 2). As it can be seen in Figure 2, the share of local budget incomes in the consolidated budget incomes of Ukraine does not have a stable trend. In 2007, this figure was 25.2\%; by 2009 there had been a decline, and already in 2010 , it was $23.3 \%$. There was a slight decline again, and since 2015 this indicator began to grow from $18.5 \%$ to $21.8 \%$. The share of expenditures of local budgets in outcomes of the Consolidated Budget of Ukraine (coefficient of decentralization by outcome) has no stable trend. In 2007, it was $74.4 \%$ by 2010 , in 2012 it was $81.6 \%$. From 2016 this indicator started to grow from $70.8 \%$ to $86.5 \%$. This was due to the growth of the State Budget of Ukraine in 2015 at a faster rate than the growth of local budget incomes. The reason for this phenomenon is related to changes in fiscal policy and partly due to the decline in macroeconomic indicators in 2014-2015.

In the current conditions the budgetary system of Ukraine is characterized by a rather high degree of centralization of budgetary resources, which testifies to the concentration of basic powers at the level of central government, the underdevelopment of local self-government and the instability of its financial system - local budgets.

However, the practice of planning, controlling and analyzing the implementation of budgets at 


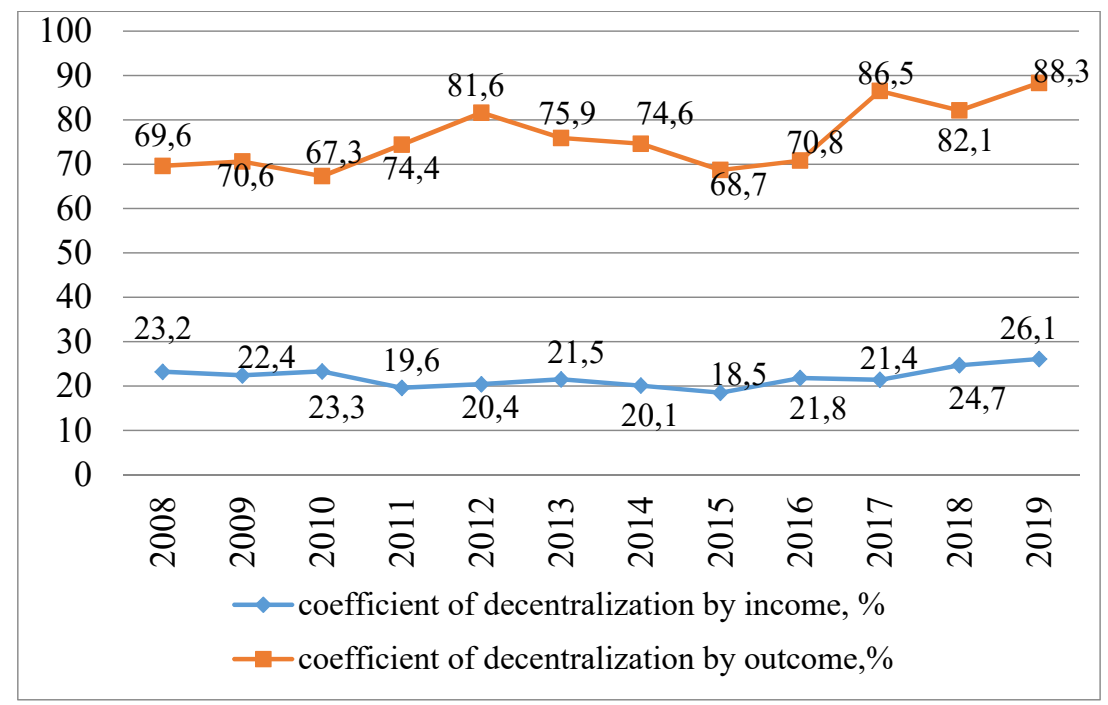

Figure 2. Dynamics of Decentralization Ratios by Income and Outcome in Ukraine, 2007-2019

Developed by the authors on the basis of [12]

all levels indicates that tax potential of the regions has a direct impact on the formation of local budget incomes, the cost of services provided by regional executive authorities, taking into account the differences between administrative units; the need for funds to support the maintenance of social and cultural facilities and support for the socially disadvantaged social groups.

Budget decentralization should ensure the effective implementation of program based budgeting at the local level, the development of a horizontal budgetary equalization at the level of administrative and territorial units, a system of indicators for evaluation and quality of financial management at the local level, while strengthening the state financial control over financial and economic activities of the local authorities.

The complexity of the subject should be taken into account when creating the model. Therefore, at the initial stage of the analysis, we should limit ourselves to only one component of fiscal decentralization: the ratio of incomes and expenditures of state budgets.

In our study, we used a standard regression model that looks like following:

$$
S_{i t}=\beta X_{i t}+\delta_{t}+u_{i}+\varepsilon_{i t},
$$

where $S_{\text {it }}$ corresponds to the decentralization indicator for period $t$ in region $\mathrm{i}$;

$X$ corresponds to the explanatory variables used in this regression;

$\delta_{t}$ is fictitious variable of year or period (temporary fixed effect);

$\beta$ is the estimation factor;

$u_{i}$ and $\varepsilon_{i t}$ are two components of rests that show a country - or region-specific effect, respectively.

In our study, the amalgamated territorial communities in 24 regions of Ukraine have been analy- zed in the context of 4 explanatory variables, namely:

- own income per inhabitant (the ratio of the amount of personal income to the number of inhabitants of the respective amalgamated territorial community);

- remoteness from the administrative center of the region;

- level of budget subsidization (the ratio of the amount of base or reverse subsidies to the total amount of incomes from the amalgamated territorial community, excluding subsidies from the state budget);

- percentage of expenditures for the maintenance of the management apparatus in the financial resources of united territorial community (the share of expenditures for the maintenance of the management apparatus of local selfgovernment bodies in the amount of own incomes of the general fund).

All the above is significant for the model; the model has no heteroskedasticity (Table 1).

Thus, according to the results of the modeling, we have come to the conclusion that the leading positions are occupied by 10 amalgamated territorial communities of Ukraine. Based on statistical data, we have developed a correlation matrix for establishing the connection between the index growth of own income per capita and the remoteness from the regional center, capital expenditures from the budgets per person, the population size of the community, percentage of administration maintenance costs and budget subsidy level (Table 2).

Conclusions. Thus, we observe a direct correlation between the amount of capital costs and the amount of own incomes of the amalgamated territorial communities, that is, the larger the capital 
Indicators of verification of the model of indicative parameters of fiscal decentralization

\begin{tabular}{|c|c|c|c|c|}
\hline & Coefficient & Statistical error & t-statistic & P-values \\
\hline const & -1531.60 & 2507.51 & -0.6108 & 0.5680 \\
\hline $\mathrm{X}$ & -14.2293 & 5.44011 & -2.616 & 0.0473 \\
\hline $\mathrm{c}$ & 515.643 & 173.829 & 2.966 & 0.0313 \\
\hline $\mathrm{b}$ & -36064.3 & 9942.01 & -3.627 & 0.0151 \\
\hline $\mathrm{n}$ & 1.68975 & 0.330542 & 5.112 & 0.0037 \\
\hline
\end{tabular}

Average of dependent variable

Sum of sq. rests

R-square

Deviation of dependent variable

Statistic error of the model

Developed and calculated by the author
10235.43

21718274

0.900315

4920.128

2084.144

Matrix of dependencies of indicative parameters of fiscal decentralization

Table 2

Correlation coefficients, observations $1-10$

$5 \%$ critical values (two-sided) $=0.6319$

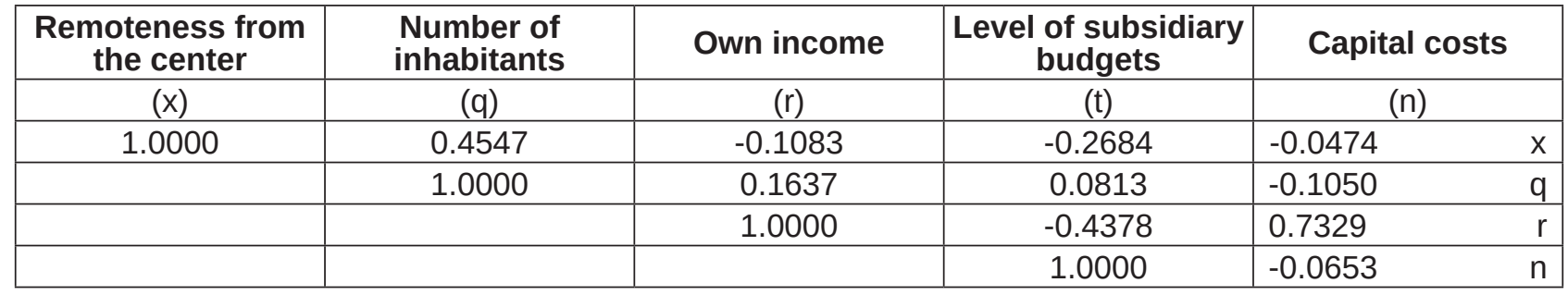

Developed and calculated by the author

expenditures, the greater the percentage of own incomes, and the inverse relationship between the population and the remoteness from the center.

Consequently, we can conclude that we introduce a term of interaction between regressors to explain the differences in the effects of fiscal decentralization between regions. For some regions, we find a positive and statistically significant effect of decentralization on the percentage of regional capital expenditures. The results show that fiscal decentralization is increasing, with the growth of government and local expenditures.
A number of suggestions can be made to address the fiscal decentralization issues mentioned above. Firstly, the existing tax system needs to be improved in order to give local authorities the power and ability to form a budget from their own sources in order to increase their autonomy in providing the necessary amount of funds. The mechanism for providing centralized state support to the regions should be further modified in order to create the conditions for activating all levers of development. It is also advisable to stimulate areas that spread economic growth.

\section{REFERENCES:}

1. Andrushchenko V.L., Kyrylenko O.P. (2001) Natsionalni skhemy biudzhetnoho federalizmu [National schemes of budgetary federalism]. Aktualni problem mizhnarodnykh vidnosyn, no. 26, pp. 67-74.

2. Bogolib T. (2015) Detcentralizatciia mestnykh biudzhetov $v$ Ukraine: problemy i perspektivy [Decentralization of local budgets in Ukraine: problems and prospects]. European cooperation, vol. 4(4), pp. 22-35.

3. Ivanov Yu., Shvabii K. (2017) Nahalni problem formuvannia derzhavnoi podatkovoi polityky v Ukraini [Urgent Problems of State Tax Policy Formation in Ukraine]. Finansy Ukrainy, no. 5, pp. 35-52.

4. Krysovatyi A. (2016) Fiskalnyi prostir staloho sotsialno-ekonomichnoho rozvytku derzhavy [Fiscal space of sustainable socio-economic development of the state]. Ternopil: TNEU. (in Ukrainian)

5. Lukianenko I.H. (2017) Systemnyi analiz formuvannia derzhavnoi polityky v umovakh makroekonomichnoi destabilizatsii [System analysis of state policy making in conditions of macroeconomic destabilization]. Kyiv: NaUKMA. (in Ukrainian)

6. Lunina I. (2016) Biudzhetna detsentralizatsiia v Ukraini u konteksti yevropeiskykh tendentsii [Budget decentralization in Ukraine in the context of European trends]. Zbirnyk naukovykh prats Natsionalnoho universytetu derzhavnoi podatkovoi sluzhby Ukrainy, no. 2, pp. 155-172. 
7. Mazaraki A.A. (ed.) (2015) Derzhavne finansove rehuliuvannia ekonomichnykh peretvoren [State financial regulation of economic transformations]. Kyiv: Kyiv.nats torh.-ekon.un-t. (in Ukrainain)

8. Sidenko V., Skrypnychenko M., Ponomarenko V., Chuhunov I. (2017) Instytucijna transformaciya finansovoekonomichnoyi systemy Ukrayiny $v$ umovah globalizaciyi [Institutional transformation of the financial and economic system of Ukraine in the conditions of globalization]. Kyiv: Kyiv.nats torh.-ekon.un-t. (in Ukrainain)

9. Fedosov V. (2016) Derzhavna borhova polityka Ukrayiny v konteksti dosvidu postsotsialistychnykh krainchleniv ES [State debt policy of Ukraine in the context of the experience of post-socialist countries-EU members]. Bila Tserkva: Vydavets Pshonkivskyi OV. (in Ukrainian)

10. Yurii S., Krysovatyi A., Maiburov I., Koschuk T. (2011) Turbulentnost nalogovykh reform [Turbulence of tax reforms]. Kyiv: Znannia. (in Russian)

11. Bondaruk T.H. (2013). Mistsevi finansy [Local finances]. Kyiv: Information and analytical agency. (in Ukrainain)

12. State Statistics Service of Ukraine. (n.d.). Materialy ofitsiinoho saitu Derzhavnoi sluzhby statystyky Ukrainy [Materials of the official site of the State Statistics Service of Ukraine]. Available at: http://www.ukrstat.gov.ual (accessed 26 December 2020).

13. Analitychna dopovid do shchorichnoho poslannia Prezydenta Ukrainy «Pro vnutrishnie ta zovnishnie stanovyshche v Ukraini» [Analytical Report to the Annual Message of the President of Ukraine "On Internal and External Situation in Ukraine"] (electronic source). Available at: http://www.niss.gov.ua/content/articles/ (accessed 26 December 2020).

14. Mistseve samovriaduvannia v Ukraini [Local self-government in Ukraine] (electronic source). Available at: http://academy.gov.ua/doc/koment-inter_prezident/2014 (accessed 26 December 2020).

15. Biudzhetnyi Kodeks Ukrainy [Budget Code of Ukraine] (electronic source). Available at: https://zakon.rada.gov.ual laws/show/2456-17 (accessed 26 December 2020).

16. Chuhunov I., Sobchuk S. (2018) Formuvannia biudzhetnoi polityky ekonomichnoho rozvytku v kraini [Formation of the budget policy of economic development of the country]. Visnyk KNTEU, no. 3, pp. 103-116.

\section{БІБЛІОГРАФІЧНИЙ СПИСОК:}

1. Андрущенко В.Л., Кириленко О.П. Національні схеми бюджетного фредералізму. Актуальні проблеми міжнародних відносин: збірник наукових праць. Київ : ВПЦ «Київський університет», 2001. Випуск 26. С. 67-74.

2. Боголиб Т. Децентрализация местных бюджетов в Украине: проблемы и перспективы. European cooperation. 2015. Випуск 4(4). С. 22-35.

3. Іванов Ю., Швабій К. Нагальні проблеми фрормування державної податкової плітики в Україні. Фінанси України. 2017. № 5. С. 39-52.

4. Крисоватий А. Фіскальний простір сталого соціально-економічного розвитку держави. моногр. / за ред. д.е.н., профр. А.І. Крисоватого. Тернопіль : ТНЕУ, 2016. 332 с.

5. Системний аналіз фрормування державної політики в умовах макроекономічної дестабілізації / за ред. д-ра екон. наук, профр. І.Г. Лук'яненко. Київ : НаУКМА, 2017. 464 с.

6. Луніна І.О. Бюджетна децентралізація в Україні у контексті європейських тенденцій. Збірник наукових праць Університету державної фріскальної служби України, 2016. № 2. С. 155-172.

7. Державне фінансове регулювання економічних перетворень: монографія / І.Я. Чугунов, А.В. Павелко, Т.В. Канєва, та ін.; за заг. ред. А.А. Мазаракі. Київ : Київ. нац. торг.-екон. ун-т, 2015. 376 с.

8. Інституційна транссрормація фрінансово-економічної системи України в умовах глобалізації: монограсрія / В.Р. Сіденко, М.І. Скрипниченко, В.С. Пономаренко, І.Я. Чугунов та ін.; за заг. ред В.Р. Сіденка. Київ : Київ. нац. торг.-екон. ун-т, 2017. 648 с.

9. Державна боргова політика україни в контексті досвіду постсоціалістичних країн-членів $€ С$ : монограсрія/ за ред. В.М. Федосова. 2016. 242 с.

10. Юрий С.И., Крисоватый А.И., Майбуров И.А., Кощук Т. Турбулентность налоговых реформ / монограсрия. Киев : Знання, 2011. 382 с.

11. Бондарук Т.Г. Місцеві фрінанси. Київ : ДП «Інфрорм.- аналіт. Агентство», 2013. 529 с.

12. Офіційний сайт державної статистичної служби України. URL: http://www.ukrstat.gov.ua/ (дата звернення: 26.12.2020).

13. Аналітична доповідь до Щорічного Послання Президента України до Верховної Ради України «Про внутрішнє та зовнішнє становище України в 2016 році». Київ : HICД, 2016. 688 c. URL: http://www.niss.gov.ua/ content/articles/ (дата звернення: 26.12.2020).

14. Місцеве самоврядування в Україні: сучасний стан та основні напрями модернізації: наук. доп. / за заг. ред. д-ра наук з держ. упр., проф. Ю.В. Ковбасюка. Київ : НАДУ, 2014. 128 c. URL: http://academy.gov.ua/doc/ koment-inter_prezident/2014 (дата звернення: 26.12.2020).

15. Бюджетний Кодекс України. URL: https://zakon.rada.gov.ua/laws/show/2456-17 (дата звернення: 26.12.2020).

16. Чугунов І., Собчук С. Формування бюджетної політики економічного розвитку країни. Вісник Київського національного торговельно-економічного університету. 2018. № 3. С. 103-116. 